The development of the immature infective lifestages appeared to be similar to that of other species.

$M$. acronea was successfully transferred to beans and tomatoes, on which reproduction took place.

1042 Park Street,

V. Comtzee

Hatfield, Pretoria,

Union of South Africa.

'Chitwood, B. G., Proc. Helminth. Soc. Wash., 16, (2), 90 (1949).

\section{Chromosome Numbers in Three Species of Uronema}

As part of a cytological investigation of members of the Ulotrichales, the following chromosome counts have been made in three species of Uronema. They are the first records for the genus.

$\begin{array}{lll}386 / 1 & \text { Uronema barlowi (Pringsheim) n.prov. } & n=18 \\ 386 / 2 a & U \text {. confervicolum Lagerh. } & n=16 \\ 386 / 3 & \text { U. gigas Vischer } & n=18\end{array}$

The serial numbers given above on the left are of the cultures used from the Cambridge Culture Collection of Algae and Protozoa.

Department of Botany,

Queen Mary College

(University of London),

Mile Find Road,

London, E.1.

March 15.

\section{Effects of Climate on Body Temperature and Respiration-rate of Buffaloes and Friesian Cattle}

Observations were made on rectal temperature and respiration-rate of five groups of animals all kept in open sheds on the University Farm, Alex. andria. Group I consisted of two buffalo cows and group II consisted of two Friesian cows, and all were in the same early stage of first lactation. The other three groups included two male calves each, from buffaloes, Friesians and native cattle. Readings of rectal temperature and respiration-rate were taken three times daily at $8.30,11.30$ a.m. and 2.30 p.m. on quietly standing animals on two days weekly for seven weeks from July 23 until September 9, 1955. Air temperature was recorded at the same intervals and ranged between $37 \cdot 2^{\circ}$ and $38 \cdot 9^{\circ} \mathrm{C}$.

There was a highly significant difference in body temperature and respiration-rate on different days and throughout the day due to different weather conditions between and during days. From Table 1 it will be seen that the mean body temperature and respiration-rate of the buffaloes was lower than those

\begin{tabular}{|c|c|c|c|c|c|c|}
\hline \multirow{2}{*}{$\begin{array}{l}\text { Comparison } \\
\text { Buffalo cows } \\
\text { Friesian cows }\end{array}$} & \multicolumn{3}{|c|}{$\begin{array}{c}\text { Mean rectal } \\
\text { temperature }\left({ }^{\circ} \mathrm{C} .\right) \\
\text { s.e. }\end{array}$} & \multicolumn{3}{|c|}{$\begin{array}{l}\text { Mean respiration- } \\
\text { rate/min. } \\
\text { s.e. }\end{array}$} \\
\hline & $\begin{array}{l}38 \cdot 39 \\
38 \cdot 64\end{array}$ & $\begin{array}{l}0.038 \\
0.040\end{array}$ & -0.25 & $\begin{array}{l}25 \cdot 08 \\
32 \cdot 76\end{array}$ & $\begin{array}{l}0 \cdot 388 \\
1 \cdot 026\end{array}$ & $-7 \cdot 68$ \\
\hline $\begin{array}{l}\text { Buffalo calves } \\
\text { Friesian calves }\end{array}$ & $\begin{array}{l}38 \cdot 34 \\
38 \cdot 66\end{array}$ & $\begin{array}{l}0.027 \\
0.036\end{array}$ & -0.32 & $\begin{array}{l}21 \cdot 30 \\
30 \cdot 26\end{array}$ & $\begin{array}{l}0.442 \\
0.706\end{array}$ & $-8 \cdot 96$ \\
\hline $\begin{array}{l}\text { Buffalo calves } \\
\text { Native calves }\end{array}$ & $\begin{array}{l}38 \cdot 34 \\
38 \cdot 51\end{array}$ & $\begin{array}{l}0.027 \\
0.025\end{array}$ & -0.17 & $\begin{array}{l}21 \cdot 30 \\
25 \cdot 86\end{array}$ & $\begin{array}{l}0.442 \\
0.498\end{array}$ & $-4 \cdot 56$ \\
\hline $\begin{array}{l}\text { Native calves } \\
\text { Friesian calves }\end{array}$ & $\begin{array}{l}38 \cdot 51 \\
38 \cdot 66\end{array}$ & $\begin{array}{l}0.025 \\
0.036\end{array}$ & $-0 \cdot 15$ & $\begin{array}{l}25 \cdot 86 \\
30 \cdot 26\end{array}$ & $\begin{array}{l}0.498 \\
0.706\end{array}$ & $-4 \cdot 40$ \\
\hline
\end{tabular}

8.e., standard error; $d$, difference. All differences are significant at the 1 per cent level. of the Friesians and the native cattle; the native calves, however, showed lower values than those of Friesian calves. The differences between all these results were highly significant.

In buffaloes, the correlation coefficient between the average daily body temperature and air temperature for eight individuals was $r=+0 \cdot 10$ and non-significant. A similar estimate obtained for the respiration-rate and air temperature was $r=+0 \cdot 28$ and highly significant. However, the correlation between body temperature and respiration-rate was $r=+0 \cdot 20$, and this was statistically significant.

For the successive days, the repeatability between readings for respiration-rate of the buffalo stock was found to be 36 per cent. Regarding body temperature, buffaloes did not tend to follow any particular pattern in this respect.

\section{K. A. Alum}

I. A. AнMED

Department of Animal Production,

Faculty of Agriculture,

University of Alexandria. Nov. 26.

\section{Scent of Otariids}

Some years ago I was engaged in an examination of the small, almost residual, herd of fur seal (Arctocephalus australis) in the Falkland Islands. In the course of it a number of animals were killed, among them several bulls, or 'wigs' in the sealer's vocabulary. After handling the bulls' skins there was left on the unwashed hands a general, not unpleasant, 'seal' smell; but after washing there remained a definite perfume rather resembling the odour emitted by the common civet when it is pleasurably excited. On one bright, sunny day, therefore somewhat warm on the rocks, I passed a few feet away from and to leeward of a bull and I was able to observe the pleasant perfume, which was definitely air-borne. If I remember rightly, this seal was a little angry. The seals on which these observations were made were all met with in summer, that is, over the rather extended breeding season.

At various times $I$ have handled fresh skins of the adult male of the southern sea lion (Otaria byronia) and on them I have observed a rather stronger and ranker odour which was undoubtedly that of the animals themselves, not of the generally insanitary terrain. This scent contained a suggestion of sweetness in it.

It seems possible that a distinctive odour produced by the adult males of the Otariidae, a family in which the bull occupies territory and waits for cows to come ashore, may be of value to the species as a direction indicator to the cows. We cannot estimate the distance at which the odour could be observed by the animals-it may be greater than we think.

It would be interesting to know if other workers on the mammals have made observations on scent, characteristic, specifically or otherwise, of the subjects. Some of us, at least, have been from childhood familiar with the 'smell of mice'.

Ross House,

J. E. HAMilton

Stanley,

Falkland Islands,

South Atlantic.

Dec. 24. 